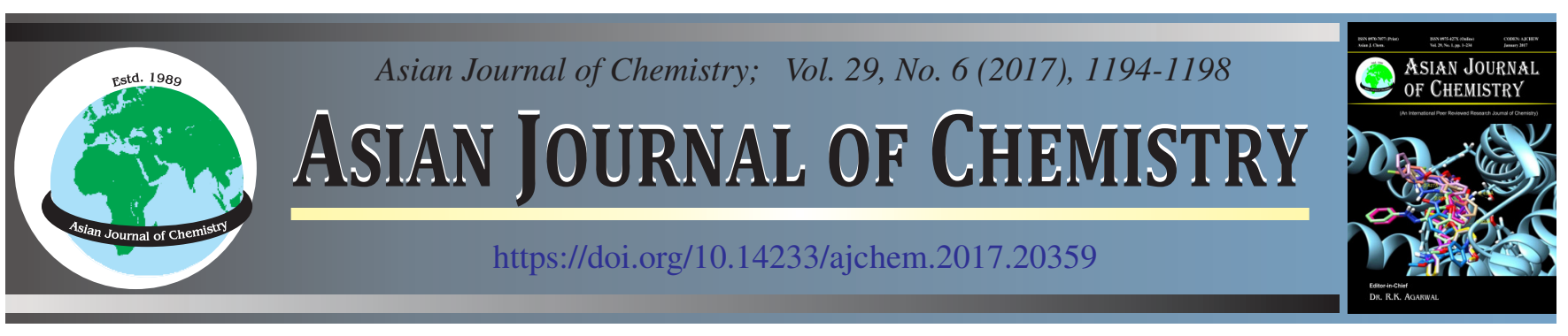

\title{
A New Versatile Tool for Isomerization: Synthesis and Characterization of Lanthanide Chloride Tridendate Schiff base Derivatives
}

\author{
SAdAF ul Hassan ${ }^{1, *}$, Faiza KAZMI $^{2}$, Rashid Abro ${ }^{3}$ and Muhammad Ammar ${ }^{3}$
}

\begin{abstract}
${ }^{1}$ Beijing National Laboratory for Molecular Sciences, State Key Laboratory of Rare Earth Materials Chemistry and Applications, College of Chemistry and Molecular Engineering, Peking University, Beijing 100871, P.R. China

${ }^{2}$ Institute of Chemistry, University of Punjab, Lahore, Pakistan

${ }^{3}$ Beijing Key Laboratory of Membrane Science \& Technology, College of Chemical Engineering, Beijing University of Chemical Technology, Beijing 100029, P. R. China
\end{abstract}

*Corresponding author: E-mail: sadafulhassan@pku.edu.cn

The different types of the tridentate Schiff base N-(2-methoxyphenyl) salicylideneamine derivative of lanthanideindenyl chloride complexes [Ind. $\mathrm{Ln} \cdot \mathrm{Schiff}$ base $\cdot \mathrm{Cl} \cdot 2 \mathrm{THF}(\mathrm{Ln}=\mathrm{Sm}, \mathrm{Eu}, \mathrm{Gd}$ and $\mathrm{Er})$ ] along with $\mathrm{NaH}$ are proved to be a versatile tool for the isomerization of 1,5hexadiene. The isomerization resulted in a mixture of hexa-1, 4-diene, hexa-2,4-diene, methylenecyclopentane and methylcyclopentene. Hexa-1,4-diene and methylenecyclopentane were the major products while hexa-2,4-diene and methylcyclopentene were the minor ones. The results showed that ligand size and radius of the metal are important factors in determining the catalytic efficiency of the complexes.

Keywords: Schiff base, Indene, Lanthanocene, Hexa-1,5-diene, Isomerization.

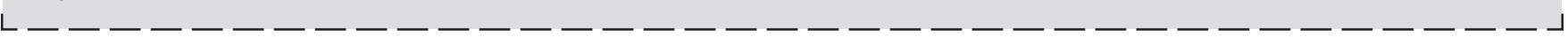

\section{INTRODUCTION}

Recently the development in organolanthnoid chemistry has primarily focused on complexes stabilized by Schiff base ligands system. Moreover, the trend of extraction of metal complex ions by Schiff based ligands is increased day by day. It was also investigated that these types of complexes have great importance in natural ionospheres [1]. On the other hand, complexes of metal hydrides are considered as vital and fundamental compounds for metallic reactions. It was observed that lanthanide alkoxide complexes along with LiOt-But resulted in high yield with narrow polydispersity of syndiotactic-rich ( $\mathrm{rr}=74$ to $80 \%$ ) polymethylmethacrylate [2]. Similarly the ring opening polymerization was successfully catalyzed by the organosamarium(II) complex and stops the co-polymerization of monomer of L-lactide [3]. Alkyl and hydro complexes of yittrium result the atactic polymerization of tert-butylacrylate and acrylonitrile. The molecular weight $\left(\mathrm{M}_{\mathrm{n}}\right)$ of acrylate polymer was found to be 720,000 with low distribution of molecular mass $\left(\mathrm{M}_{\mathrm{w}} / \mathrm{M}_{\mathrm{n}}=1.50-2.00\right)$ while the molecular mass of acrylonitrile polymer was observed to be greater than 105 but the polydispersity $\left(\mathrm{M}_{\mathrm{w}} / \mathrm{M}_{\mathrm{n}}\right)$ was found to be greater than five [4]. The aryloxosamarium(II) complex showed high activity (yield $=99 \%, M_{n}=120,000, M_{w} / M_{n}=$ 1.40 ) for the ring opening polymerization of $\varepsilon$-caprolactone
[5]. On the other hand organolanthanoid complexes can also be successfully cyclopolymerized the neat hexa-1,5-dieneto poly (methylene-1,3-cyclopentadiene) rather than promoting the cyclization of methylenecyclopentane [6]. The hydrides of the lanthanide metals were previously explained for interstitial metallic components and such types of simple hydrides were used for many years [7]. The literature survey verifies that lanthanide complexes are key factors for the rapid development in the field of organo lanthanoid chemistry. The investigations concerning lanthanide complexes with Schiff bases have been devoted to their syntheses, structural studies and biological application of metal enzymes or protein bondings. Schiff base ligands are privileged ligands because they can easily be synthesized by the condensation of imines and aldehydes. Schiff base ligands can coordinate different kinds of metals and stabilize these metals in different oxidation states, enabling the use of Schiff base complexes for the huge quality of important catalytic transformations [8]. Previously huge quantity of Schiff bases metal complexes were studied for investigating their different properties such as their reversibly binding of oxygen, activity of catalyst for the olefins's hydrogenation, transfer of amino group, photochromic properties, complexation ability towards toxic metals and catalytic synthesis of polymethylmethacrylate and isomerization of hexa-1,5-diene [9-12]. Schiff base derivatives of ruthenium(III) 
complexes isomerized effectively the $o$-allyl systems such as 1,4-diallyloxybutane and 4-allyloxybutane-1-ol [13]. The catalysts showed the stereo-selectivity in the migration of double bond of allyl family to 1-propyl group and high selectivity of allyloxy alcohol's isomerization to cyclic acetal [14].

In another study, a high mass poly ( $\beta$-pinene) having strong output efficiency was prepared by using Schiff base nickel complexes blended with methylaluminoxane. It was also found that ligand structure had a considerable impact on the polymerization with respect to its molecular mass and productivity [15]. Later on it was also observed that Schiff base ruthenium complexes reveal a high chemo-selectivity and high activity in a range of different catalytic processes such as dimerization of alkyne, ring closing and ring opening metathesis polymerization and synthesis of enol ester [16]. Keeping in mind the Schiff base derivatives of lanthanide complexes were prepared.

\section{EXPERIMENTAL}

Sodium hydride was washed with THF and dried under vacuum. Hexa-1,5-diene was dried over $\mathrm{CaH}_{2}$ and was distilled under argon. Lanthanide complexes (Table-1) along with a co-catalyst $(\mathrm{NaH})$ were used for the isomerization of hexa1,5-diene. Following general procedure was used for this isomerization reaction. A $25 \mathrm{~mL}$ Schlenk flask fitted with a Teflon stopcock was charged under argon with $0.067 \mathrm{~g}(0.10$ $\mathrm{mmol}$ ) of the lanthanide complex and $0.15 \mathrm{~g}$ of $\mathrm{NaH}$. Then THF ( $4 \mathrm{~mL}$ ) was poured to it with constant stirring, cooled to $-78{ }^{\circ} \mathrm{C}$. $0.165 \mathrm{~g}(0.24 \mathrm{~mL})$ hexa-1,5-diene was introduced to it. The mixture was allowed to warm up to $60^{\circ} \mathrm{C}$. The reaction mixture was quenched after the respected time (Table-4) with $1 \mathrm{~mL}$ of methanol. The mixture was distilled under reduced pressure condition and the distillate compound was collected in the Schlenk flask at $-78^{\circ} \mathrm{C}$. The distillate thus obtained was injected into the GLC equipment and the isomerized products were identified by comparing their chromatograms with that standard ones.

$\mathbf{C}_{31} \mathbf{H}_{35} \mathbf{N O}_{4} \mathbf{S m C l}(\mathbf{1}): \mathrm{m} / z$ (\%): 372.5 ( $\mathbf{M}^{+}$-Indenyl-THF$\mathrm{Cl} 100), 483.5$ ( $\mathrm{M}^{+}$-Schiff base-THF-Cl 56.5), 115 (indenyl 2.7), 226 (Schiff base 1.5), 72 (THF 2.5) Anal. $\mathrm{C}_{31} \mathrm{H}_{35} \mathrm{NO}_{4} \mathrm{SmCl}$. Calcd: C, 55.481; H, 5.225; N, 2.083. Found: C, 55.521; H, $5.024 ; \mathrm{N}, 2.063$.

$\mathbf{C}_{31} \mathbf{H}_{35} \mathbf{N O}_{4} \mathbf{E u C l}(2): \mathrm{m} / z$ (\%):374.5 (M+-Indenyl-THF$\mathrm{Cl} 100), 485.5$ ( $\mathrm{M}^{+}$-Schiff base-THF-Cl 55.7), 115 (Indenyl 2.5), 226 (Schiff base 1.9) 72 (THF 2.1) Anal. $\mathrm{C}_{31} \mathrm{H}_{35} \mathrm{NO}_{4} \mathrm{EuCl}$. Calcd: C, 55.323; H, 5.205; N, 2.087 Found: C, 55.291; H, $5.212 ; \mathrm{N}, 2.093$.
$\mathbf{C}_{31} \mathbf{H}_{35} \mathbf{N O}_{4} \mathbf{G d C l}(3): \mathrm{m} / \mathrm{z}(\%): 379.5\left(\mathbf{M}^{+}\right.$-Indenyl-THFCl 100), 490.5 ( $\mathrm{M}^{+}$-Schiff base-THF-Cl 56.7), 115 (Indenyl 2.3), 226 (Schiff base 2.0) 72 (THF 2.5) Anal. $\mathrm{C}_{31} \mathrm{H}_{35} \mathrm{NO}_{4} \mathrm{GdCl}$. Calcd: C, 54.713; H, 5.175; N, 2.077 Found: C, 54.761; H, 5.203; N, 2.094.

$\mathbf{C}_{31} \mathbf{H}_{35} \mathbf{N O}_{4} \mathbf{E r C l}(4): \mathrm{m} / z$ (\%): 389.5 (M+-Indenyl-THF$\mathrm{Cl} 100), 500.5$ ( $\mathrm{M}^{+}$-Schiff base-THF-Cl 55.9), 115 (Indenyl 2.5), 226 (Schiff base 2.4) 72 (THF 2.9) Anal. $\mathrm{C}_{31} \mathrm{H}_{35} \mathrm{NO}_{4} \mathrm{ErCl}$. Calcd: C, 54.115; H, 5.097; N, 2.049 Found: C, 54.143; H, $5.125 ; \mathrm{N}, 2.077$.

\section{RESULTS AND DISCUSSION}

The tridentate Schiff base [N-(2-methoxyphenyl)salicylideneamine] was synthesized by refluxing equimolar quantities of purified salicylaldehyde and anisidene in toluene for $5 \mathrm{~h}$. The tridentate Schiff base derivatives of lanthanide complexes used for this study were synthesized and characterized with the help of elemental analyses and mass spectrometric technique. For this purpose equimolar quantity of the anhydrous chloride of the respective lanthanoide element ( $\mathrm{Sm}, \mathrm{Eu}, \mathrm{Gd}$ and Er) was reacted with sodium salt of indene in THF in order to get the indenyl derivative of lanthanoide dichloride complex. Then this complex was reacted with an equimolar quantity of sodium salt of tridentate Schiff base in THF in order to get the tridentate Schiff base derivative of indenyl lanthanoidechloride complexes [17,18] (Scheme-I).

The titled lanthanide complexes 1-4 derived from tridentate Schiff base (Table-1) are applied in order to study the isomerization of hexa-1,5-diene (Scheme-II) under different reaction conditions viz. catalyst co-catalyst, reaction temperature and reaction time.

Since the catalytic efficiency of complex $\mathbf{1}\left(\mathrm{C}_{31} \mathrm{H}_{35} \mathrm{NO}_{4} \mathrm{SmCl}\right)$ was observed better than other attempted complexes (Table-1), therefore for simplification this complex was used as a representative of all the attempted complexes in order to study the effect of catalyst, temperature, catalyst/substrate ratio and time on the isomerization of hexa-1,5-diene. At $60^{\circ} \mathrm{C}$ all the complexes 1-4 favour the production of linear isomer such as hexa1,4-diene. The percentage of 1, 4-hexadiene was maximum $(84.6 \%)$ in case of complex 1 while it was minimum $(57.8 \%)$ for complex 4. Similarly, the conversion of hexa-1,5-diene into cyclic isomers especially methylenecyclopentane was found maximum $(24.2 \%)$ in case of complex 4 while was observed minimum $(11.8 \%$ ) for the complex 2 . Overall the conversion percentage of complex 1 was observed maximum (28.7\%) while other complexes (2-4) showed 25.8, 25.7 and $20.6 \%$ respectively. The reason is the ionic radius of samarium is

TABLE-1

EFFECT OF CATALYST ON ISOMERIZATION OF 1,5-HEXADIENE*

\begin{tabular}{|c|c|c|c|c|c|c|}
\hline \multirow[b]{2}{*}{ Catalyst } & \multirow[b]{2}{*}{ Conversion (\%) } & \multicolumn{4}{|c|}{ Selectivity (\%) } & \multirow[b]{2}{*}{ Linear/cyclic } \\
\hline & & & & & & \\
\hline $\mathrm{C}_{31} \mathrm{H}_{35} \mathrm{NO}_{4} \mathrm{SmCl}$ & 29.6 & 84.6 & 2.6 & 13.5 & 5.6 & $87.2 / 19.1$ \\
\hline $\mathrm{C}_{31} \mathrm{H}_{35} \mathrm{NO}_{4} \mathrm{EuCl}$ & 26.8 & 80.3 & 2.9 & 11.8 & 4.9 & $83.2 / 16.7$ \\
\hline $\mathrm{C}_{31} \mathrm{H}_{35} \mathrm{NO}_{4} \mathrm{GdCl}$ & 25.7 & 74.0 & 8.4 & 14.1 & 4.6 & $82.4 / 18.7$ \\
\hline $\mathrm{C}_{31} \mathrm{H}_{35} \mathrm{NO}_{4} \mathrm{ErCl}$ & 20.6 & 57.8 & 9.6 & 24.2 & 9.6 & $67.4 / 33.8$ \\
\hline $\mathrm{ErCl}_{3}$ & 0.8 & 50.0 & 50.0 & Trace & Trace & - \\
\hline
\end{tabular}

Reaction conditions: Catalyst/hexadiene (1:20), catalyst/ $\mathrm{NaH}$ (1:50), $24 \mathrm{~h}$ at $60{ }^{\circ} \mathrm{C}$ in $\mathrm{THF}$. 

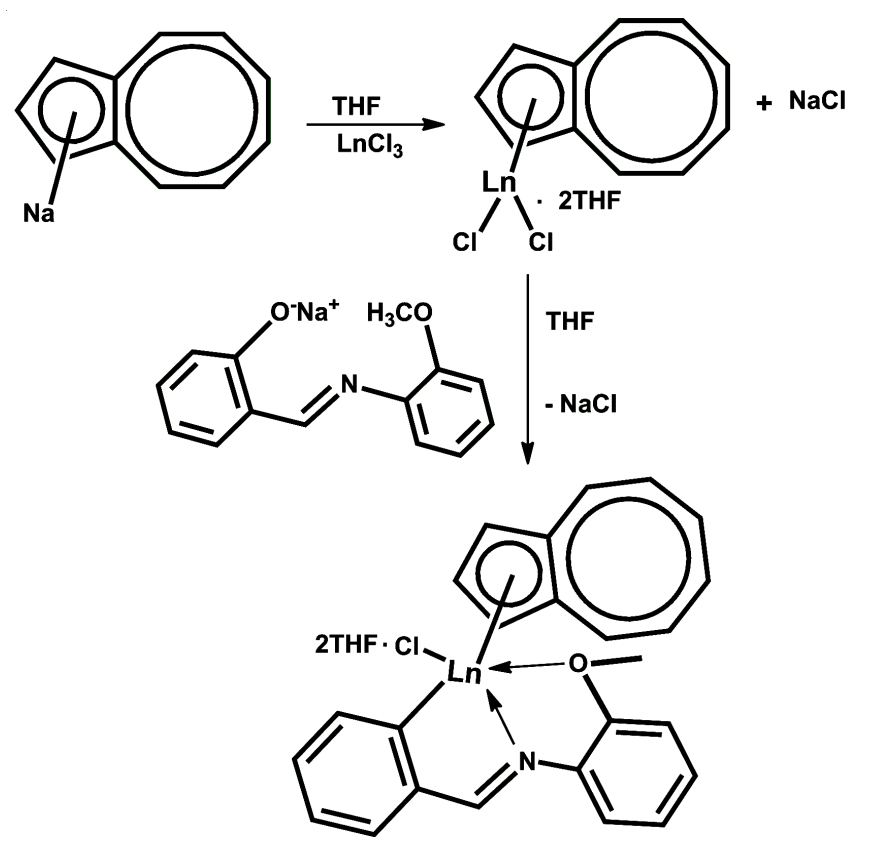

Ln $=\mathrm{Sm}, \mathrm{Eu}, \mathrm{Gd}, \mathrm{Er}$

Scheme-I: Preparation of the catalyst

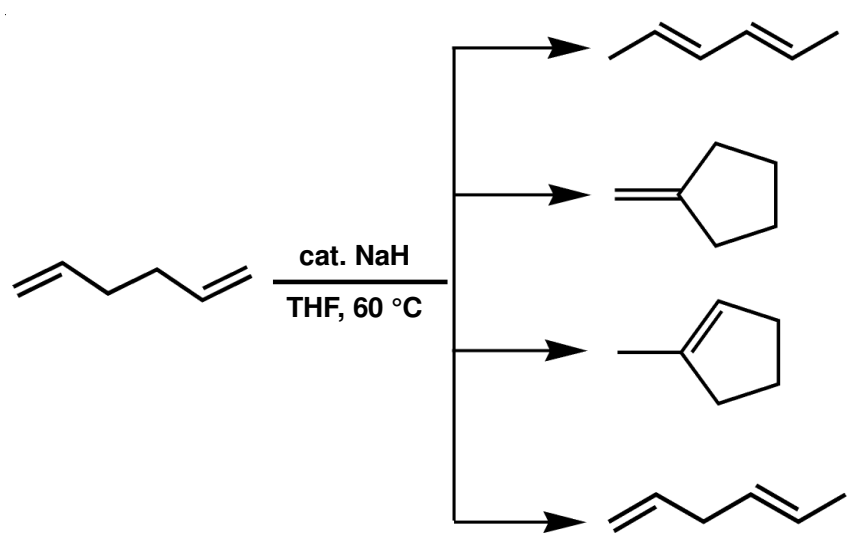

Scheme-II: Isomerization of hexa-1,5-diene in the presence of lanthanides complexes

larger than europium, gadolinium and erbium and hence the coordination sphere in case of complex $\mathbf{1}$ is larger than complexes 2, $\mathbf{3}$ and 4, respectively. The coordination sphere of the metal is directly proportional to the coordination number and hence the catalytic efficiency of catalyst is also increased. That is why, complex 1 exhibited maximum conversion (28.7 $\%$ ) while catalyst 4 showed minimum (20.6\%). Further there was not found any remarkable activity with $\mathrm{ErCl}_{3} / \mathrm{NaH}$ system.

Effect of temperature (Table-2), indicates that the conversion of hexa-1,5-diene into its isomers increases with the temperature being maximum $(29.6 \%)$ at $60{ }^{\circ} \mathrm{C}$ and minimum $(8.5 \%)$ at $30{ }^{\circ} \mathrm{C}$. Moreover the1,4-hexadiene was observed the prominent isomer at higher temperature $\left(60^{\circ} \mathrm{C}\right)$ while at lower temperature methylene cyclopetane was found the major component. Conclusively the catalytic efficiency was observed appreciable at $60^{\circ} \mathrm{C}$ (Fig. 1). Earlier similar types of the results were observed with organotitanium complexes [19].

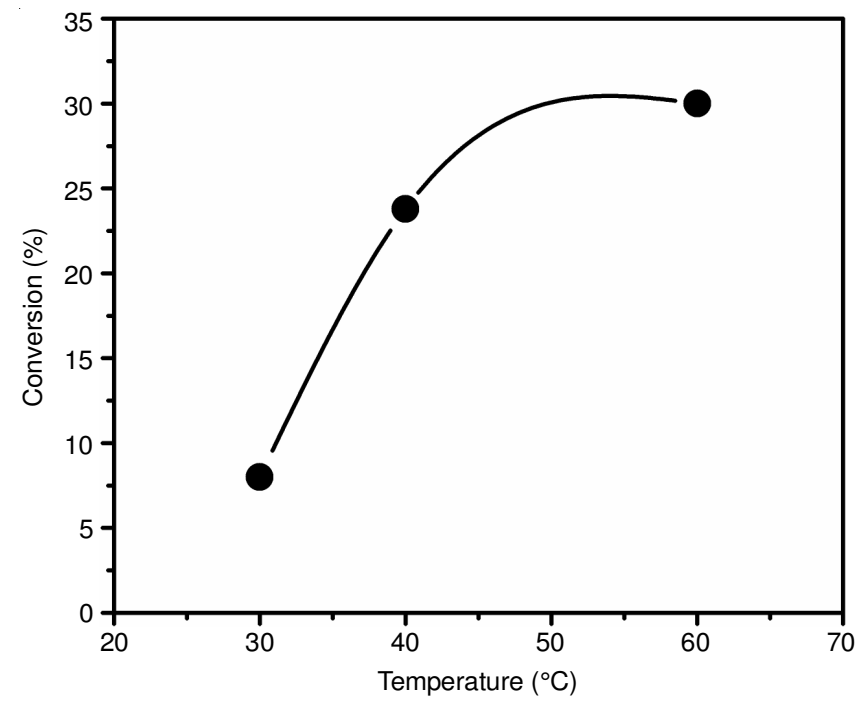

Fig. 1. Effect of temperature $\left({ }^{\circ} \mathrm{C}\right)$ on the isomerization of hexa-1,5-diene

The effect of catalyst/substrate molar ratio explains (Table-3 and Fig. 2) that in case of 1:10-1:20 molar ratio, there was no significant difference in the conversion of hexa-1,5diene into either linear ( 85.5 and $81.6 \%$ ) products or cyclic (11.3 and $13.2 \%$ ) ones. However, a remarkable difference was found at 1:40 molar ratio. The percentage of 1,4-hexadiene was observed smaller (44.2\%) than others but the percentage of methylene cyclopentane was higher at this molar ratio than $1: 10$ and 1:20 respectively. This justifies that the product is directly depend on the amount of the catalyst, which is in accordance with results reported earlier [20].

The effect of time (Table-4 and Fig. 3) shows that up to $10 \mathrm{~h}$, the catalytic efficiency of the catalyst was very rapid, being $25.4 \%$, but during further $10 \mathrm{~h}$, it was comparatively slower $26.8 \%$, after this there was no significant increase $(27.5 \%)$ in the converted products. Conclusively isomerization of 1,5-hexadiene can be completed during $20 \mathrm{~h}$ by using such type of catalytic system. The mechanism is proceeded by the reaction of the titled complex $\mathbf{1}$ with $\mathrm{NaH}$ in THF in order to produce indenyl lanthanide hydride derivative which is the active species for the isomerization of 1,5-hexadiene. At first step it interacts with the double bond of either 1-position or of

TABLE-2

EFFECT OF TEMPERATURE ON ISOMERIZATION OF 1,5-HEXADIENE

\begin{tabular}{|c|c|c|c|c|c|c|}
\hline \multirow[b]{2}{*}{ Temperature $\left({ }^{\circ} \mathrm{C}\right)$} & \multirow[b]{2}{*}{ Conversion (\%) } & \multicolumn{4}{|c|}{ Selectivity (\%) } & \multirow[b]{2}{*}{ Linear/cyclic } \\
\hline & & & & & & \\
\hline 30 & 8.5 & 28.8 & 4.9 & 51.0 & 18.2 & $33.7 / 69.2$ \\
\hline 45 & 22.4 & 74.2 & 3.7 & 17.5 & 4.9 & $77.9 / 22.4$ \\
\hline 60 & 29.6 & 81.5 & 2.6 & 14.2 & 3.7 & $84.1 / 17.9$ \\
\hline
\end{tabular}

Reaction conditions: Catalyst/NaH (1:50) catalyst/1,5-hexadiene (1:20), 24 h, in THF. 


\begin{tabular}{|c|c|c|c|c|c|c|}
\hline \multicolumn{7}{|c|}{$\begin{array}{c}\text { TABLE-3 } \\
\text { EFFECT OF MOLE RATIO OF CATALYST/HEXADIENE ON ISOMERIZATION OF 1,5-HEXADIENE }\end{array}$} \\
\hline \multirow{2}{*}{$\begin{array}{l}\text { Mole ratio } \\
\text { catalyst/HD }\end{array}$} & \multirow[b]{2}{*}{ Conversion $(\%)$} & \multicolumn{4}{|c|}{$\begin{array}{l}\text { Selectivity }(\%) \\
\end{array}$} & \multirow[b]{2}{*}{ Linear/cyclic } \\
\hline & & & crest t & & & \\
\hline $1: 10$ & 29.8 & 85.5 & 3.7 & 11.3 & 5.5 & $89.2 / 16.8$ \\
\hline $1: 20$ & 27.7 & 81.6 & 2.6 & 13.2 & 7.6 & $84.2 / 20.8$ \\
\hline $1: 40$ & 15.3 & 44.2 & 12.4 & 33.4 & 11.5 & $56.6 / 44.9$ \\
\hline \multicolumn{7}{|c|}{ Reaction conditions: Catalyst/NaH $\left(1: 5024 \mathrm{~h}\right.$ at $60^{\circ} \mathrm{C}$ in $\mathrm{THF}$. } \\
\hline \multicolumn{7}{|c|}{$\begin{array}{c}\text { TABLE-4 } \\
\text { EFFECT OF TIME ON ISOMERIZATION OF 1,5-HEXADIENE }\end{array}$} \\
\hline \multirow[b]{2}{*}{ Time (h) } & \multirow[b]{2}{*}{ Conversion $(\%)$} & \multicolumn{3}{|c|}{ Selectivity $(\%)$} & & \multirow[b]{2}{*}{ Linear/cyclic } \\
\hline & & & & & & \\
\hline 1 & 4.9 & 6.2 & 17.4 & 53.7 & 19.7 & $26.6 / 73.4$ \\
\hline 5 & 8.5 & 6.5 & 33.2 & 41.9 & 19.4 & $38.4 / 61.3$ \\
\hline 10 & 25.4 & 77.7 & 3.2 & 11.2 & 9.0 & $84.8 / 15.2$ \\
\hline 20 & 26.8 & 83.2 & 2.3 & 11.1 & 4.2 & $84.7 / 15.3$ \\
\hline 30 & 27.5 & 80.6 & 2.4 & 12.4 & 4.6 & $83.0 / 17.0$ \\
\hline
\end{tabular}

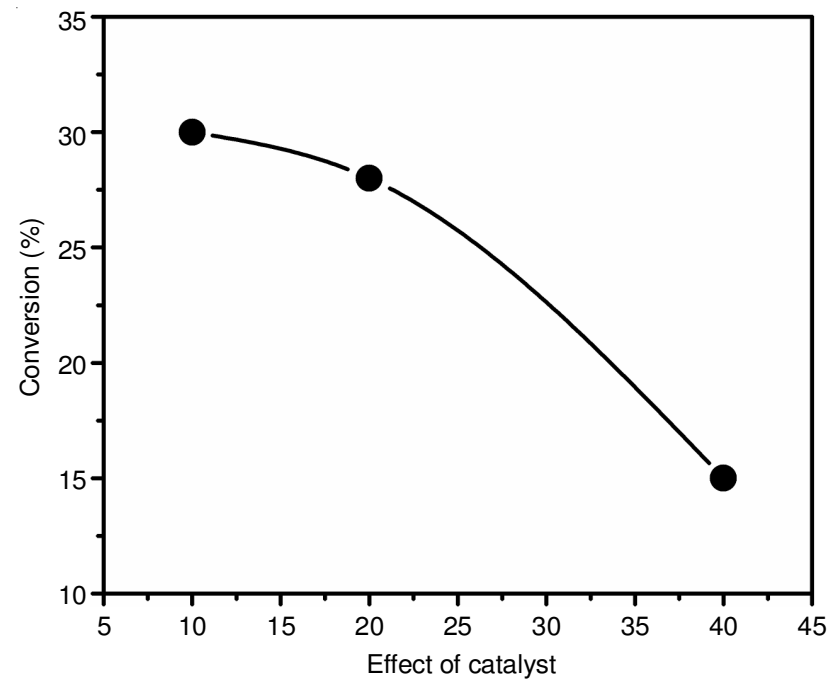

Fig. 2. Effect of catalyst/hexa-1,5-diene molar ratio on this isomerization reaction

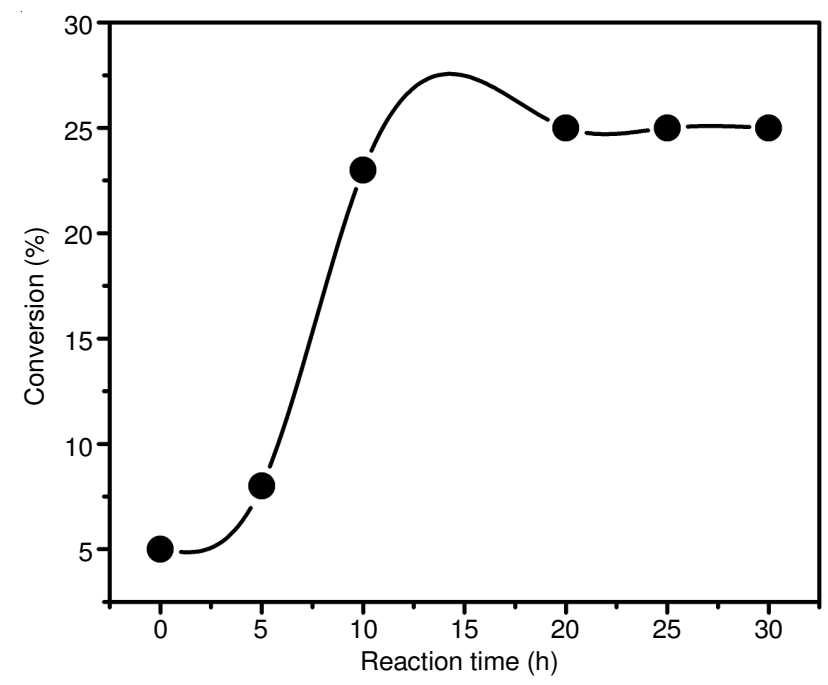

Fig. 3. Effect of time on the isomerization of hexa-1,5-diene 5-position in different fashions in order to produce two intermediates. The one intermediate is converted first into another intermediate (methylene cyclohexane) after passing through a chain process which is ultimately converted into an end product (methyl cyclohexene). The second intermediate migrate the double bond from 1-position to 2-postion and then 3-position, respectively. The proposed mechanism is represented by the following reaction (Scheme-III). (i) $\left(\mathrm{C}_{9} \mathrm{H}_{7}\right) \mathrm{LnSbCl}(\mathrm{THF})_{2}+\mathrm{NaH} \stackrel{\mathrm{THF}}{-78{ }^{\circ} \mathrm{C}}\left(\mathrm{C}_{9} \mathrm{H}_{7}\right) \mathrm{LnSb}(\mathrm{m}-\mathrm{H})(\mathrm{THF})_{2}+\mathrm{NaCl}$
(ii) $\left(\mathrm{C}_{9} \mathrm{H}_{7}\right) \mathrm{LnSb}(\mathrm{m}-\mathrm{H})(\mathrm{THF})_{2} \stackrel{\mathrm{C}_{9} \mathrm{H}_{7} \mathrm{Ln}}{\rightleftharpoons}$

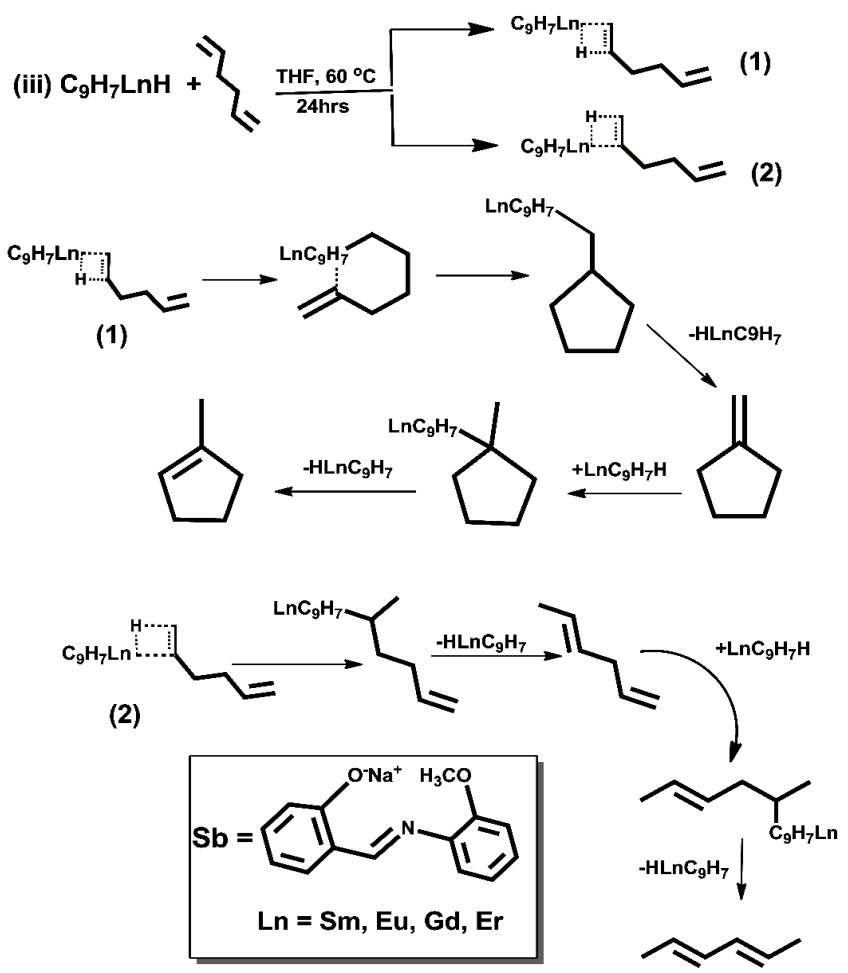

Scheme-III: Mechanistic pathway of isomerization of hexa-1,5-diene 


\section{Conclusion}

In conclusion, we found in the present work that the different types of tridentate Schiff base N-(2-methoxyphenyl)salicylideneamine derivative of lanthanideindenyl chloride complexes along with $\mathrm{NaH}$ are efficient for the isomerization of 1,5-hexadiene. The results showed that size and radius of the metal are important factors for the catalytic efficiency of the complexes. Further Schiff base ligands have ability to stabilize different types of metals in several oxidation states along with creating strong coordination between them. Continuing efforts will be focused on the syntheses of new kinds of Schiff bases with improved catalytic properties.

\section{REFERENCES}

1. J. Gromada, J. Spanswick and K. Matyjaszewski, Macromol. Chem. Phys., 205, 551 (2004);

https://doi.org/10.1002/macp.200300082.

2. D. Cui, T. Tang, W. Bi, J. Cheng, W. Chen and B. Huang, J. Polym. Sci. A Polym. Chem., 41, 2667 (2003); https://doi.org/10.1002/pola.10814.

3. K. Hultzsch, T. Spaniol and J. Okuda, Angew. Chem. Int. Ed., 38, 227 (1999);

https://doi.org/10.1002/(SICI)1521-3773(19990115)38:1/2<227::AIDANIE227>3.0.CO;2-M

4. M. Nishiura, Z. Hou, T. Koizumi, T. Imamoto and Y. Wakatsuki, Macromolecules, 32, 8245 (1999); https://doi.org/10.1021/ma9901011.

5. C. Schaverien, J. Mol. Catal., 90, 177 (1994); https://doi.org/10.1016/0304-5102(94)00008-5.

6. W.M. Mueller, Metal Hydrides, Academic Press, New York, edn 4 (1968).
7. P.G. Cozzi, Chem. Soc. Rev., 33, 410 (2004); https://doi.org/10.1039/B307853C.

8. R.D. Jones, D.A. Summerville and F. Basolo, Chem. Rev., 79, 139 (1979); https://doi.org/10.1021/cr60318a002.

9. H.O. Gisela, The Chemistry of the Catalyzed Hydrogenation of Carbon Monoxide, Springer Verlag, Berlin, Germany, edn 3 (1984).

10. V.H. Dugas and C. Penny, Bioorganic Chemistry-A Chemical Approach to Enzyme Action, Springer-Verlag, Berlin, pp. 508 (1981).

11. J.D. Margerum and L.J. Miller, Photochromism, Wiley-Interscience, New York USA, edn 3 (1971)

12. W. Sawodny and M. Riederer, Angew. Chem. Int. Ed. Engl., 16, 859 (1977);

https://doi.org/10.1002/anie.197708591.

13. M. Yousaf, J.U. Huang, Z.F. Feng, Y.L. Qian, J.Q. Sun and Z.D. Pan, Chin. J. Chem., 18, 759 (2000); https://doi.org/10.1002/cjoc. 20000180519.

14. Q. Yanlong, S. Abu, J. Huang and L. Zhengwei, Chin. J. Catal., 21, 1 (2000).

15. M. Szypa, M. Urbala, Z. Rozwadowski and T. Dziembowska, Transition Met. Chem., 33, 855 (2008); https://doi.org/10.1007/s11243-008-9122-7.

16. F.Y. Li, D.G. Ward, S.S. Reddy and S. Collins, Macromolecules, 30, 1875 (1997); https://doi.org/10.1021/ma961472u

17. R. Drozdzak, B. Allaert, N. Ledoux, I. Dragutan, V. Dragutan and F. Verpoort, Adv. Synth. Catal., 347, 1721 (2005); https://doi.org/10.1002/adsc.200404389.

18. M. Yousaf, Q. Liu, J. Huang and Y. Qian, Chin. J. Chem., 18, 740 (2000); https://doi.org/10.1002/cjoc.20000180515.

19. R.E. Maginn, S. Manastyrskyj and M. Dubeck, J. Am. Chem. Soc., 85, 672 (1963); https://doi.org/10.1021/ja00889a007.

20. Q. Liu, M. Ding, Y. Lin and Y. Xing, Polyhedron, 17, 555 (1998); https://doi.org/10.1016/S0277-5387(97)00335-5. 